\title{
Pathogenesis of Shigella Diarrhea \\ XVI. Selective Targetting of Shiga Toxin to Villus Cells of Rabbit Jejunum Explains the Effect of the Toxin on Intestinal Electrolyte Transport
}

\author{
Gabor Kandel," Arthur Donohue-Rolfe, ${ }^{*}$ Mark Donowitz, ${ }^{\ddagger}$ and Gerald T. Keusch* \\ ${ }^{*}$ Division of Geographic Medicine and Infectious Diseases, Department of Medicine, New England Medical Center/Tufts University \\ School of Medicine, Boston, Massachusetts 02111; and ${ }^{\ddagger}$ Departments of Medicine and Physiology, The Johns Hopkins University \\ School of Medicine, Baltimore, Maryland 21205
}

\begin{abstract}
To examine the mechanism by which Shiga toxin alters intestinal water and electrolyte transport, ligated loops of rabbit jejunum were incubated in vivo with purified toxin and then studied in vivo by single pass perfusion and in vitro by the Ussing chamber voltage-clamp technique. Toxin exposure led to accumulation of water in the jejunal lumen, associated with decreased active basal $\mathrm{NaCl}$ absorption. Glucose- and alaninestimulated $\mathrm{Na}$ absorption were also reduced, while toxin had no effect on either basal short-circuit current or the secretory response to theophylline. These observations suggest that Shiga toxin selectively inhibits $\mathrm{NaCl}$ absorption without significantly altering active anion secretion. To localize the cellular site of toxin action, populations of villus and crypt cells from rabbit jejunum were isolated and studied. Villus cells had a greater content of the glycolipid Shiga toxin receptor, Gb3, had more toxin binding sites than did crypt cells, and were much more sensitive than crypt cells to toxin-induced inhibition of protein synthesis. These experiments demonstrate that purified Shiga toxin inhibits jejunal fluid absorption without affecting active fluid secretion by a preferential effect on villus cells. The results suggest that this is due to the differential distribution of toxin receptors on villus compared to crypt cells.
\end{abstract}

\section{Introduction}

Shiga toxin is a multimeric protein toxin produced by Shigella dysenteriae 1 (1). When placed into intestinal loops in animals, the toxin induces the luminal accumulation of water and electrolytes (enterotoxicity) (2). This observation has led to the suggestion that the toxin may play a role in the pathogenesis of the diarrhea that occurs in Shigella infections. There is also evidence that similar, closely related toxins act as virulence factors in disease due to other Shigella species and in pathogenesis of hemorrhagic colitis caused by Escherichia coli 0157:H7 (3).

\footnotetext{
Address reprint requests to Dr. Keusch, Division of Geographic Medicine and Infectious Diseases, Department of Medicine, New England Medical Center, Tufts University School of Medicine, 750 Washington Street, Box 041, Boston, MA 02111.

Received for publication 17 June 1988 and in revised form 16 May 1989.
}

J. Clin. Invest.

(C) The American Society for Clinical Investigation, Inc.

0021-9738/89/11/1509/09 \$2.00

Volume 84, November 1989, 1509-1517
Experiments with in vitro cell-free systems have demonstrated that Shiga toxin catalytically inactivates the eukaryotic $60 \mathrm{~S}$ ribosomal subunit (4) by specifically modifying a single adenine base at position 4324 in the $28 \mathrm{~S}$ rRNA, thereby interrupting cellular protein synthesis (5). This RNA $N$-glycosidase activity may explain the ability of Shiga toxin to kill susceptible cells in tissue culture (cytotoxicity) and, possibly, to cause limb paralysis and death when parenterally administered to susceptible animal species (neurotoxicity). Although depression of protein synthesis has been speculated to be responsible for the enterotoxic activity of Shiga toxin (1), no plausible mechanism has been proposed. In fact, cycloheximide-mediated inhibition of intestinal mucosal protein synthesis inhibits secretagogue-induced fluid secretion $(6,7)$.

The goal of the present study was to examine the effects of purified Shiga toxin on electrolyte and water transport in mature rabbit jejunum to better understand the mechanism by which it induces fluid secretion. We chose rabbit jejunum as a model because earlier studies indicated that this tissue responds to Shiga toxin with net secretion of fluid in the absence of gross histological changes (8). Our studies suggest that villus, but not crypt, epithelial cells in rabbit jejunum are susceptible to Shiga toxin. This selectivity may explain the effects of Shiga toxin on intestinal electrolyte transport.

\section{Methods}

Shiga toxin was purified from $S$. dysenteriae 1 , strain $60 \mathrm{R}$, as previously described (9). The purified toxin caused detachment of susceptible HeLa cells, with a specific activity of $4 \times 10^{7} \mathrm{CD}_{50} / \mathrm{mg}$ toxin protein.

Male New Zealand albino rabbits, weighing $2-2.5 \mathrm{~kg}$, were maintained on standard rabbit chow diet with free access to water, but not to food, for 12-18 h before experiments. Animals were anesthetized with intramuscular injections of a combination of xylazine $(5 \mathrm{mg} / \mathrm{kg})$, acepromazine maleate $(0.75 \mathrm{mg} / \mathrm{kg})$, and ketamine $(55 \mathrm{mg} / \mathrm{kg})$, and killed with $\mathrm{Na}$ pentobarbitol $(100 \mathrm{mg} / \mathrm{kg}$ i.v.).

In vivo intestinal transport studies. Two adjacent, but separate, closed jejunal loops, each $10 \mathrm{~cm}$ in length, were constructed beginning $5 \mathrm{~cm}$ distal to the entry of the pancreatic duct. The loops were washed gently with $50 \mathrm{ml}$ of PBS, and inoculated with either purified Shiga toxin, $50 \mu \mathrm{g}$ in $1 \mathrm{ml}$ of PBS, or $1 \mathrm{ml}$ of PBS alone. The loops were then returned to the abdomen. After $3 \mathrm{~h}$, both jejunal loops were cannulated and washed with $100 \mathrm{ml}$ of warm PBS during a 20-min period. Water transport was then determined in vivo by the single pass perfusion technique using the nonabsorbable marker, PEG as previously described (10). Loops were perfused at a constant temperature $\left(37^{\circ} \mathrm{C}\right)$, and rate $(0.5 \mathrm{ml} / \mathrm{min})$ with a peristaltic pump (model 1203; Harvard Apparatus Co., Millis, MA) while maintaining body temperature at $37^{\circ} \mathrm{C}$ with a thermocouple controlled heating lamp. Perfusion consisted of a 60 -min steady state period followed by nine 20 -min collection periods. The perfusion solution was Ringer's- $\mathrm{HCO}_{3}(\mathrm{pH} 7.4$, os- 
molarity $275 \mathrm{mosM} / \mathrm{kg}$ ) composed of the following (in $\mathrm{mM}$ ) $\mathrm{NaCl} 115$, $\mathrm{NaHCO}_{3} 25, \mathrm{~K}_{2} \mathrm{HPO}_{4}$ 2.4, $\mathrm{KH}_{2} \mathrm{PO}_{4} \quad 0.4, \mathrm{CaCl}_{2} 1.2$, and $\mathrm{MgCl}_{2}$ 1.2. $\left[{ }^{14} \mathrm{C}\right]$ PEG $(4,000 \mathrm{~mol} \mathrm{wt} ; 0.01 \mu \mathrm{Ci} / \mathrm{ml}$; New England Nuclear, Boston, MA) and unlabeled PEG ( $2 \mathrm{~g} /$ liter $)$ were added to the perfusate as nonabsorbable water markers. The perfusate was continually gassed with $95 \% \mathrm{O}_{2}-5 \% \mathrm{CO}_{2}$. Water transport was calculated as previously described (10) and expressed as microliters/hour-centimeter length of loop. For each perfusion period, $\left[{ }^{14} \mathrm{C}\right] \mathrm{PEG}$ recovery was calculated, and periods during which PEG recovery was not $95-105 \%$ were discarded. Absorption from the lumen is expressed as a positive value and secretion into the lumen as a negative value and reported as the mean \pm SEM.

In vitro intestinal transport studies. Active electrolyte transport in rabbit jejunal mucosa was measured during the time period in which intestinal water secretion induced by Shiga toxin was documented by the single pass perfusion studies described above. Adjacent closed jejunal loops, starting distal to the entry of the pancreatic duct, were inoculated in vivo with $50 \mu \mathrm{g}$ Shiga toxin in $1 \mathrm{ml}$ of PBS, or $1 \mathrm{ml}$ of PBS alone. After $3 \mathrm{~h}$, the animals were killed, the jejunal loops were removed, the muscularis propria and serosa were stripped away, and active electrolyte transport was determined by the Ussing chambervoltage clamp technique, as previously described (11). Mucosa was mounted as a flat sheet between two modified lucite Ussing chambers having an aperture of $1.13 \mathrm{~cm}^{2}$, bathed with Ringer's- $\mathrm{HCO}_{3}$ at $37^{\circ} \mathrm{C}$, and prepared for measurement of transmural potential difference (PD), ${ }^{1}$ short-circuit current $\left(\mathrm{I}_{\mathrm{sc}}\right)$, conductance $(G)$, and undirectional fluxes of $\mathrm{Na}$ and $\mathrm{Cl}$. At the beginning of the experiment, glucose $\left(10^{-2}\right.$ M) was added to the serosal bathing solution and mannitol $\left(10^{-2} \mathrm{M}\right)$ was added to the mucosal bath. An automatic voltage clamp (World Precision Instruments, Inc., New Haven, CT; model DVC 1000) corrected for fluid resistance between the PD sensing bridges and provided continuous short-circuiting of the tissue. Unidirectional fluxes of $\mathrm{Na}$ and $\mathrm{Cl}$ were measured $20-80 \mathrm{~min}$ after addition of the isotopes ${ }^{22} \mathrm{Na}$ and ${ }^{36} \mathrm{Cl}$ as previously described (11). To study stimulated active electrolyte transport, either glucose $\left(10^{-2} \mathrm{M}\right)$ or alanine $\left(3 \times 10^{-2} \mathrm{M}\right)$ was added to the mucosal bathing solution, or theophylline $\left(10^{-2} \mathrm{M}\right)$ was added to the serosal bathing solution (11). In some studies, two 20-min flux periods were determined in Shiga toxin exposed and control intestinal mucosal sheets and then $10^{-8} \mathrm{M}$ tetrodotoxin (Sigma Chemical Co., St. Louis, MO) was added to the serosal surface and two further 20-min flux periods were determined.

Enterocyte isolation. Villus and crypt epithelial cells were isolated from rabbit jejunum by a modification of the method of Weiser (12). Rabbits were killed by an overdose of Na pentobarbitol, the jejunum was removed, and the lumen was then washed with ice-cold PBS containing $1 \mathrm{mM}$ DTT (Bethesda Research Laboratories, Gaithersburg, $\mathrm{MD})$. The lumen was then filled with warm oxygenated solution $\mathrm{A}$ $\left(\mathrm{NaCl} 96 \mathrm{mM}, \mathrm{KCl} 1.5 \mathrm{mM}, \mathrm{KH}_{2} \mathrm{PO}_{4} 8 \mathrm{mM}, \mathrm{Na}_{2} \mathrm{HPO}_{4} 5.6 \mathrm{mM}\right.$, sodium citrate $27 \mathrm{mM}, \mathrm{pH} \mathrm{7.4)}$ ) at $37^{\circ} \mathrm{C}$ for $15 \mathrm{~min}$. The contents of the loops were discarded and the loop lumen was then successively filled with warm, oxygenated solution $\mathrm{B}\left(\mathrm{Ca}^{2+}\right.$ - and $\mathrm{Mg}^{2+}$-free PBS containing $1.5 \mathrm{mM}$ EDTA, $0.5 \mathrm{mM}$ DTT) for the following time intervals (in minutes): $5,7,5,4,4,12,30,60$. All incubations were carried out by immersing the filled loops in a beaker of PBS in a shaking water bath maintained at $37^{\circ} \mathrm{C}$ and gassing with $95 \% \mathrm{O}_{2}-5 \% \mathrm{CO}_{2}$. Enterocyte fractions were obtained at the end of each time interval by collecting loop lumen contents in conical centrifuge tubes, which were immediately centrifuged at $400 \mathrm{~g}$ for $5 \mathrm{~min}$ at $4^{\circ} \mathrm{C}$. Cells were washed twice with Ringer's- $\mathrm{HCO}_{3}\left(\mathrm{pH} \mathrm{7.4,} 4^{\circ} \mathrm{C}\right)$ and viability was assessed by exclusion of $0.5 \%$ trypan blue in PBS. In addition, morphology of the intestinal mucosa remaining after the isolation of each epithelial cell fraction was studied by light microscopy of formalin fixed, hematoxylin and eosin-stained paraffin sections.

Epithelial cell fractions were characterized by measuring the activ-

1. Abbreviations used in this paper: $G$, conductance; HPTLC, high performance thin layer chromatography; $I_{s c}$, short circuit current; PD, potential difference. ity of the villus cell marker brush border enzymes sucrase and alkaline phosphatase, and by determining the incorporation of $\left[{ }^{3} \mathrm{H}\right]$ thymidine into cellular DNA (indicative of crypt cell enrichment). Sucrase activity was assayed by measuring the liberation of glucose from sucrose by the method of Dahlqvist (13). Alkaline phosphatase activity was measured as described by Weiser (12) using p-nitrophenyl phosphate as substrate ( $1 \mathrm{U}$ of alkaline phosphatase activity is defined as the liberation of $1 \mu \mathrm{mol}$ of $p$-nitrophenyl phosphate $/ \mathrm{min} / \mathrm{mg}$ of enterocyte protein). $\left[{ }^{3} \mathrm{H}\right]$ Thymidine incorporation was measured by a modification of the method of Lentze et al. (14). Equal amounts of cell protein $(800$ $\mu \mathrm{g})$ from each epithelial cell fraction were incubated in triplicate with $1.5 \mathrm{ml}$ of Leibowitz L-15 medium (Gibco Laboratories, Grand Island, NY) supplemented with $2 \mathrm{mM}$ glutamine, $100 \mathrm{U} / \mathrm{ml}$ penicillin, 100 $\mu \mathrm{g} / \mathrm{ml}$ streptomycin, and $15 \mu \mathrm{Ci} / \mathrm{ml}$ of $\left[{ }^{3} \mathrm{H}\right]$ thymidine $(50-80 \mathrm{Ci} /$ $\mathrm{mmol}$; New England Nuclear). Cells were incubated at $37^{\circ} \mathrm{C}$ in $95 \%$ air-5\% $\mathrm{CO}_{2}$ for $20 \mathrm{~min}$, and sonicated over ice with six 30-s bursts in a sonicator equipped with a microtip (Branson Sonic Power Co., Danbury, CT). An aliquot was taken for protein determination, and the remainder of the sonicate was precipitated with an equal volume of $20 \% \mathrm{TCA}$ at $4^{\circ} \mathrm{C}$. After washing twice with $10 \% \mathrm{TCA}$ at $4^{\circ} \mathrm{C}$, the pellet was dissolved in $0.5 \mathrm{~N} \mathrm{NaOH}$ and an aliquot was added to Ready-Solv (Beckman Instruments, Inc., Cedar Grove, $\mathrm{NJ}$ ) for scintillation counting. Data are expressed as a percentage of peak $\left[{ }^{3} \mathrm{H}\right]$ thymidine incorporation (counts per minute per milligram of cell protein).

All protein determinations used the Bio-Rad protein assay kit (Bio-Rad Laboratories, Richmond, CA).

Measurement of protein synthesis in epithelial cells. The effect of Shiga toxin on cellular protein synthesis was evaluated by determining the incorporation of $\left[{ }^{3} \mathrm{H}\right]$ leucine into epithelial cells in vitro during incubation with purified Shiga toxin by a modification of the method described by Koo et al. (15). 800- $\mu$ g aliquots of washed villus cells (epithelial fraction 2) and crypt cells (epithelial fraction 8) were incubated in triplicate in $95 \%$ air- $5 \% \mathrm{CO}_{2}$ with $1 \mathrm{ml}$ of leucine-deficient minimal essential medium (MEM) with Earle's salts (Irvine Scientific, Santa Ana, CA) supplemented with $100 \mathrm{U} / \mathrm{ml}$ penicillin and $100 \mu \mathrm{g} / \mathrm{ml}$ streptomycin. Shiga toxin or cycloheximide (used as a positive control) were added in varying concentrations to the media. After $30 \mathrm{~min}$ of incubation, $\left[{ }^{3} \mathrm{H}\right]$ leucine $(>140 \mathrm{Ci} / \mathrm{ml}$; New England Nuclear) was added to the media (final concentration, $5 \mathrm{Ci} / \mathrm{ml}$ ), and the incubation continued for a further $15 \mathrm{~min}$. Incubation was terminated by emersing all tubes in an ice-water slurry. The cells were then centrifuged at $20,000 \mathrm{~g}$, and washed three times with PBS. An aliquot was taken for protein determination. The remainder of the cellular protein was solubilized in $0.5 \mathrm{M} \mathrm{KOH}$, precipitated with an equal volume of $20 \% \mathrm{TCA}$ at $4^{\circ} \mathrm{C}$, and washed twice with $10 \% \mathrm{TCA}$ at $4^{\circ} \mathrm{C}$. The TCA precipitate was then solubilized in $0.5 \mathrm{~N} \mathrm{NaOH}$, and an aliquot of this material was added to Ready-Solv for scintillation counting. Results are expressed as a percentage of the untreated control values in counts per minute per milligram protein.

Binding of ${ }^{125}$ I-Shiga toxin to isolated rabbit jejunal epithelial cells. Purified Shiga toxin was iodinated by a modification of the chloramine $T$ method as previously described (9). Specific activity of the iodinated toxin preparation ranged from 15,000 to $30,000 \mathrm{cpm} / \mathrm{ng}$ toxin protein. Iodinated toxin appeared identical to native toxin on SDS-polyacrylamide gels and the radiolabeled toxin was fully active in the HeLa cell cytotoxicity assay (9).

Binding studies were performed in triplicate with a modification of the rapid filtration technique, as previously described (16). Aliquots of washed isolated villus cells (epithelial fraction 2) or crypt cells (epithelial fraction 8 ) were incubated in PBS containing $0.1 \%$ BSA with varying concentrations of ${ }^{125}$ I-labeled toxin with or without a 500 -fold excess of unlabeled toxin. Incubation was terminated after $45 \mathrm{~min}$ by filtration under negative pressure through $22-\mu \mathrm{m}$ polyvinylidene difluoride filters (Durapore; Millipore Corp., Beford, MA). The filters were then washed three times with $5 \mathrm{ml}$ of ice cold PBS- $0.1 \%$ BSA, air dried, and the radioactivity was counted in a gamma counter. Specific binding was determined as the difference between binding in the absence of unlabeled toxin ("total binding") and binding in the presence 
of a 500-fold excess of cold toxin ("nonspecific binding"). Nonspecific binding was always $<10 \%$ of total binding.

Binding of ${ }^{125}$ I-Shiga toxin to SDS-polyacrylamide gels of rabbit jejunal epithelial cells. ${ }^{125}$ I-toxin binding to rabbit jejunal epithelial cells was determined on SDS-PAGE gels, as previously described (17). $50-\mu \mathrm{g}$ aliquots of each of the eight epithelial cell fractions obtained as described above were homogenized with a Dounce (loose) homogenizer, and sonicated over ice with six 30-s bursts using a Branson microtip sonifier. The fractions were then solubilized in denaturing buffer ( $2 \%$ SDS, $1 \%$ glycerol, $20 \mu \mathrm{g}$ bromphenol blue $/ \mathrm{ml}$, in $0.5 \mathrm{M}$ Tris, $\mathrm{pH}$ 6.8) and electrophoresed using an $11 \%$ polyacrylamide SDS slab gel, $1.5 \mathrm{~mm}$ thick, as described by Dharmalingam and Goldberg (18). Gels were stained with $0.125 \%$ Coomassie brilliant blue, incubated overnight in destain (73\% water, $20 \%$ methanol, $7 \%$ acetic acid) and then equilibrated in a $0.15 \mathrm{M} \mathrm{NaCl}, 0.05 \mathrm{M}$ Tris- $\mathrm{HCl}, 0.1 \%$ sodium azide, pH 7.4 buffer, as described by Burridge (19). The gel was next incubated for $12 \mathrm{~h}$ at room temperature in the same buffer containing ${ }^{125}$ I-toxin $(100,000 \mathrm{cpm} / \mathrm{ml})$ and hemoglobin $(1 \mathrm{mg} / \mathrm{ml})$ as a carrier protein. Finally, the gel was washed for $48 \mathrm{~h}$ with several changes of buffer, dried, and autoradiograms prepared by exposure to Kodak $\mathrm{X}$-omat $\mathrm{AR}$ film at $-70^{\circ} \mathrm{C}$ using an intensifying screen.

Cholera toxin was obtained commercially (List Biological Laboratories, Campbell, CA) and iodinated by the same chloramine T technique used for Shiga toxin. The specific activity was $8,000 \mathrm{cpm} / \mathrm{ng}$. Binding studies similar to those described above with ${ }^{125}$ I-labeled Shiga toxin were then performed with ${ }^{125}$ I-labeled cholera toxin.

Immunoperoxidase staining of Shiga toxin bound to rabbit jejunum. Binding of purified, unlabeled Shiga toxin to intact rabbit jejunal mucosa was evaluated by a single-sandwich immunoperoxidase technique using polyclonal antiserum to Shiga toxin generated in rabbits and previously characterized in our laboratory (9). A gamma globulin fraction of this serum was obtained by repeated ammonium sulfate precipitation according to the method of Hudson and Hay (20). Biotinylation was performed by the method of Bayer and Wilchek (21). To $8 \mathrm{ml}$ of gamma globulin ( $1 \mathrm{mg} / \mathrm{ml}$ in $\left.0.1 \mathrm{M} \mathrm{NaHCO}_{3}, \mathrm{pH} 9.0\right)$ was added $1 \mathrm{ml}$ of DMSO containing $1 \mathrm{mg} / \mathrm{ml} \mathrm{N}$-hydroxysuccinimide (Sigma Chemical Co.). The reaction mixture was incubated at $23^{\circ} \mathrm{C}$ for $4 \mathrm{~h}$, dialyzed against $1,000 \mathrm{vol}$ of PBS, concentrated (such that $1 \mathrm{ml}$ of the initial antitoxin serum corresponded to $4.2 \mathrm{ml}$ of biotinylated anti-toxin antibody), and stored at $-70^{\circ} \mathrm{C}$ until used. Immunoprecipitation of ${ }^{125}$ I-toxin with Staphylococcus aureus protein A showed that toxin binding by the biotinylated gamma globulin preparation was comparable to that of the gamma globulin fraction before biotinylation.

Pieces of normal rabbit jejunum were gently washed with ice cold PBS, embedded in Tissue TEK II (Miles Laboratories, Inc., Elkhart, IN) and rapidly frozen in liquid nitrogen. Microscopic sections $(11 \mu \mathrm{m}$ thick) were placed on glass slides, air dried for at least $1 \mathrm{~h}$, fixed in ice-cold acetone, and overlaid with Shiga toxin, $1 \mu \mathrm{g} / \mathrm{ml}$, in PBS for $1 \mathrm{~h}$ at $4^{\circ} \mathrm{C}$. After washing, the slides were overlaid at $4^{\circ} \mathrm{C}$ with the following solutions, with washing between each step, except as indicated: $0.3 \%$ hydrogen peroxide in methanol for $30 \mathrm{~min}$; normal rabbit serum, $15 \mu \mathrm{g} / \mathrm{ml}$ in PBS, for $20 \mathrm{~min}$ (no wash); biotinylated polyclonal antibody directed against Shiga toxin, diluted 1:100 in PBS, for $1 \mathrm{~h}$; avidin-biotinylated horseradish peroxidase macromolecular complex (Vector Laboratories, Burlingame, CA) for $1 \mathrm{~h}$. Tissue-bound peroxidase was then visualized with $0.1 \%$ diaminobenzidine tetrahydrochloride in $0.1 \mathrm{M}$ Tris, $\mathrm{pH} 7.2$ containing $0.01 \%$ hydrogen peroxide. Slides were counterstained with hematoxylin and prepared for light microscopy.

Lipid analysis. To compare the relative villus cell and crypt cell concentrations of the previously described Shiga toxin $\mathrm{Gb} 3$ glycolipid receptor $(22,23)$, aliquots of rabbit jejunal villus cells (epithelial fraction 2) or crypt cells (epithelial fraction 8) were adjusted to $1 \mathrm{mg}$ protein $/ \mathrm{ml}$ in PBS and extracted with isopropanol/hexane/water $(55: 25: 20)$, dried in a rotary evaporator, washed, and solubilized in 100 $\mu \mathrm{l}$ of $2: 1$ chloroform/methanol, as previously described (22). $5 \mu \mathrm{l}$ of this material was then spotted on high performance thin layer chromatog- raphy plates (HPTLC S1 plates; J. T. Baker Chemical Co., Phillipsburg, NJ) and separated by upward flow of chloroform/methanol/ water $(50: 40: 10)$ containing $0.02 \% \mathrm{CaCl}_{2}$. Dried plates were sprayed for $1 \mathrm{~min}$ with $0.5 \%$ BSA in PBS, soaked in the same solution for $2 \mathrm{~h}$, and then incubated for $4 \mathrm{~h}$ at $4^{\circ} \mathrm{C}$ with this same buffer containing ${ }^{125}$ I-labeled toxin $(200,000 \mathrm{cpm} / \mathrm{ml})(22)$. After washing with several changes of buffer, the plates were air-dried overnight and either exposed to Kodak X-omat $\mathrm{AR}$ film using an intensifying screen or sprayed with $0.5 \%$ orcinol in $10 \%$ aqueous $\mathrm{H}_{2} \mathrm{SO}_{4}$, followed by heating for $5 \mathrm{~min}$ at $100^{\circ} \mathrm{C}$ to visualize the glycolipid bands. Authentic Gb3 was purified from human type $B$ erythrocyte membranes by high performance liquid chromatography, as previously described (24) for use as a standard, and was a gift from Dr. S.-I. Hakomori, University of Washington, Seattle, WA.

Statistical analyses were performed with Student's two-tailed $t$ tests for paired and unpaired data; linear regression analyses were performed by the method of least squares.

\section{Results}

Effect of Shiga toxin on rabbit jejunal water and electrolyte transport. Purified Shiga toxin altered jejunal water transport as measured by the single pass perfusion technique in rabbit jejunal loops (Fig. 1). When studied between 260 and $420 \mathrm{~min}$, after inoculation of either toxin or buffer, toxin-treated loops accumulated water at a constant rate (mean rate $-23.2 \pm 13.8$ $\mu \mathrm{l} / \mathrm{h}-\mathrm{cm} ; n=13)$ compared to control loops in which net water absorption occurred (mean rate $27.9 \pm 11.4 \mu \mathrm{l} / \mathrm{cm}-\mathrm{h} ; n=13)(P$ $<0.01$ ). It should be noted that this continuing secretion occurred in toxin-exposed jejunum even though the intestine was thoroughly washed $3 \mathrm{~h}$ after toxin inoculation, and that toxin did not interfere with $\left[{ }^{14} \mathrm{C}\right] \mathrm{PEG}$ recovery (data not shown).

To determine if Shiga toxin was inducing luminal water accumulation by altering active electrolyte transport, toxinexposed mucosa was studied with the Ussing chamber voltage-clamp technique. Ligated jejunal loops were preincubated in vivo with toxin $(50 \mu \mathrm{g}$ in $1 \mathrm{ml}$ of PBS) or PBS alone $(1 \mathrm{ml})$

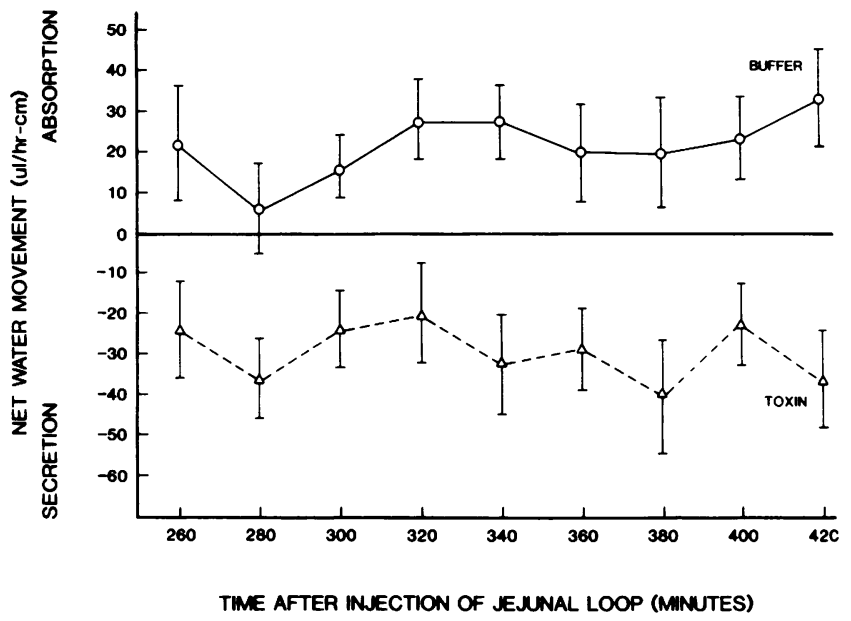

Figure 1. Effect of Shiga toxin on net water transport in rabbit jejunum. Closed ligated loops of rabbit jejunum were inoculated with $50 \mu \mathrm{g}$ Shiga toxin (triangles) or PBS (circles). $3 \mathrm{~h}$ later the loops were washed and cannulated, and water transport was determined during nine consecutive 20 -min periods by the single pass perfusion technique using $\left[{ }^{14} \mathrm{C}\right] P E G$ as a nonabsorbable water marker. Results are expressed as the mean $\pm \operatorname{SE}(n=13$ animals). The difference in water transport between buffer-incubated and toxin-incubated loops was significant $(P<0.05)$ for all time points. 
Table I. Effects of Shiga Toxin Exposure on Rabbit Jejunal Active Electrolyte Transport

\begin{tabular}{|c|c|c|c|c|c|c|c|c|c|}
\hline Additions & $I_{\mathbf{s c}}$ & PD & G & $\mathrm{J}_{\mathbf{m s}^{*}}^{\mathrm{Na}}$ & $\mathrm{J}_{\mathrm{sm}^{\mathrm{Na}}}^{\mathrm{Na}}$ & $J_{\text {net }}^{\mathrm{Na}}$ & $\mathrm{J}_{\mathrm{ms}}^{\mathrm{G}}$ & $\mathrm{J}_{\mathrm{sm}}^{\mathrm{C}}$ & $J_{\text {net }}^{\mathrm{C}}$ \\
\hline Buffer & $2.28 \pm 0.21$ & $-3.7 \pm 0.3$ & $16.6 \pm 1.0$ & $7.77 \pm 0.87$ & $6.53 \pm 0.33$ & $1.24 \pm 0.74$ & $6.90 \pm 0.88$ & $6.74 \pm 0.35$ & $0.16 \pm 0.84$ \\
\hline Shiga toxin & $2.17 \pm 0.18$ & $-3.2 \pm 0.4$ & $17.9 \pm 2.7$ & $6.23 \pm 1.00$ & $6.76 \pm 0.71$ & $-0.53 \pm 0.26$ & $4.79 \pm 0.59$ & $6.57 \pm 0.85$ & $-1.78 \pm 0.70$ \\
\hline$P$ value & NS & NS & NS & $<0.05$ & NS & $<0.05$ & $<0.01$ & NS & $<0.05$ \\
\hline
\end{tabular}

Closed loops of rabbit jejunum were inoculated with either $50 \mu \mathrm{g}$ Shiga toxin or buffer for $3 \mathrm{~h}$, the mucosa removed and studied with the Ussing chamber-voltage clamp technique between 260 and $340 \mathrm{~min}$ after initial toxin exposure. Units of $\mathrm{I}_{\mathrm{sc}}$ and ion fluxes were in $\mu \mathrm{eq} / \mathrm{cm}^{2}-\mathrm{h} ; \mathrm{PD}$, $\mathrm{mV} ; \mathrm{G}, \mathrm{mS} / \mathrm{cm}^{2}$. Results were mean $\pm \mathrm{SE}$; flux results are for five experiments for control and toxin-treated animals and electrical data are from nine experiments for control and toxin-treated treated animals. $P$ values are a comparison of toxin-inoculated and buffer exposed tissue (unpaired $t$ test). NS, no significant difference. ${ }^{*}$ ms, mucosa to serosa unidirectional flux. ${ }^{\ddagger}$ sm, serosa to mucosa unidirectional flux performed as described in Methods.

for $3 \mathrm{~h}$. These jejunal loops then were removed, washed, the serosa and muscularis propria were removed, and the mucosa mounted in Ussing chambers. Electrolyte transport was studied beginning $260 \mathrm{~min}$ after initial in vivo inoculation of the loops with toxin. In this manner, electrolyte transport was evaluated during the time of toxin-induced water secretion experimentally determined in vivo as above. Table I shows that short-circuit current and conductance were not significantly different in control (PBS incubated) and toxin incubated tissues. Measurement of net ${ }^{22} \mathrm{Na}$ and ${ }^{36} \mathrm{Cl}$ fluxes revealed that $\mathrm{Na}$ and $\mathrm{Cl}$ transport were not significantly different than zero in control jejunum and that net secretion of both ions was occurring in toxin-exposed jejunum. These decreases in net transport were significant compared to control values. Analysis of unidirectional fluxes showed that toxin-induced net ion secretion was a consequence of diminished mucosato-serosa $\mathrm{Na}$ and $\mathrm{Cl}$ fluxes, while serosa-to-mucosa fluxes were not significantly affected (Table I). These experiments were performed with tissues exposed first to toxin in vivo since direct addition of toxin to jejunal mucosa in vitro did not alter transport when studied for $120 \mathrm{~min}$ after inoculation (data not shown).

These results suggested that Shiga toxin inhibits $\mathrm{Na}$ and $\mathrm{Cl}$ absorption without stimulating electrogenic $\mathrm{Cl}$ secretion. To further investigate this hypothesis, stimulated active secretion

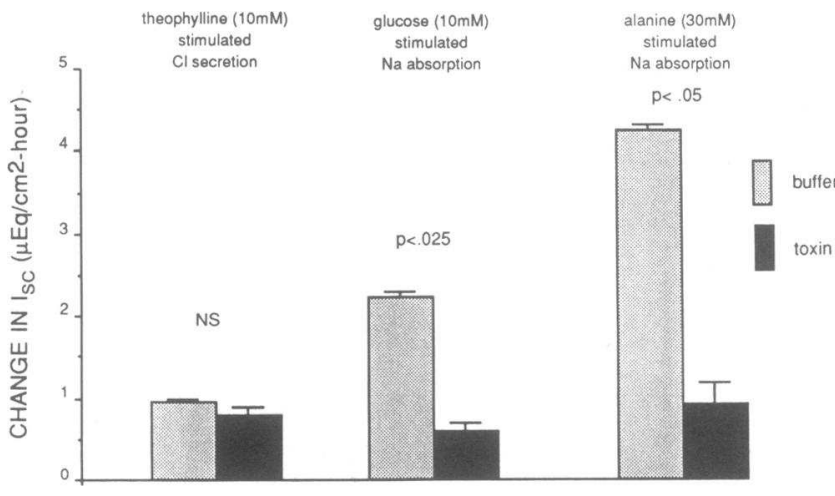

Figure 2. Effect of Shiga toxin on stimulated active electrolyte transport in rabbit jejunum. The method employed was identical to that described in the legend to Table I and in Methods. 120 min after mounting the tissue in Ussing chambers, $10 \mathrm{mM}$ theophylline was added to the serosal bath, or $10 \mathrm{mM}$ glucose or $30 \mathrm{mM}$ alanine were added to the mucosal bath. Results are expressed as the mean $\pm \mathrm{SE}$ ( $n$ $=9$ animals for theophylline and glucose and 3 for alanine). $P$ values are based on the comparison between toxin-incubated and buffer-incubated tissues by paired $t$ test. was studied with the Ussing chamber-voltage clamp technique. Addition of $10 \mathrm{mM}$ theophylline to the serosal bath, known to stimulate anion secretion and increase short-circuit current (25), resulted in comparable increases in short-circuit current in both the toxin-exposed and control tissues (Fig. 2), suggesting that anion secretion was not affected by Shiga toxin. To determine if toxin induced inhibition of $\mathrm{Na}$ and $\mathrm{Cl}$ absorption extended to substrate-dependent $\mathrm{Na}$ absorption, the short-circuit current response to mucosal glucose $(10 \mathrm{mM})$ or alanine ( $30 \mathrm{mM})$ was evaluated. The response to both mucosal glucose and alanine in toxin exposed jejunum was blunted in comparison to the response in buffer incubated jejunum (Fig. 2), consistent with inhibition of glucose- and alanine-stimulated $\mathrm{Na}$ absorption.

To determine whether the Shiga toxin effect was exerted by stimulation of enteric nerves, tetrodotoxin was added to the serosal surface of buffer and toxin-treated tissue and fluxes determined. Tetrodotoxin stimulated net $\mathrm{Na}$ and $\mathrm{Cl}$ absorption in control tissue as expected, but failed to significantly increase $\mathrm{Na}$ and $\mathrm{Cl}$ absorption in Shiga toxin treated tissue (Table II).

Effect of Shiga toxin on protein synthesis in vitro in isolated rabbit jejunal epithelial cells. Considerable evidence indicates that electrolyte absorption occurs in intestinal villus cells while $\mathrm{Cl}$ secretion occurs chiefly in crypt cells (25). Accordingly, we explored the hypothesis that the observed effects were due to selective inhibition of the ion absorbing cells without a significant effect on the ion secreting cells. The first set of experiments was designed to determine whether Shiga toxin alters protein synthesis in villus and crypt cells in equivalent fashion. A villus-crypt gradient of epithelial cells was isolated from rabbit jejunum. Cells were eluted in a villus tip to crypt cell gradient, with an approximately fivefold difference in marker enzyme activity between fraction 2 and fraction 8 (Fig. 3). Histological examination of the intestinal mucosa after isolation of fraction 2 demonstrated loss of only villus cells, whereas after fraction 8 nearly all epithelial cells, including most crypt cells, were absent (results not shown). In all further experiments fraction 2 was therefore used to represent the villus cells and fraction 8 to represent the crypt cells.

Villus and crypt cells were then incubated in vitro with varying concentrations of Shiga toxin $(1 \mathrm{ng} / \mathrm{ml}$ to $10 \mu \mathrm{g} / \mathrm{ml})$, and pulsed with $\left[{ }^{3} \mathrm{H}\right]$ leucine in order to measure the incorporation of isotope from the medium into TCA precipitable cellular protein. In untreated villus cells, $\left[{ }^{3} \mathrm{H}\right]$ leucine incorporation was $2.9 \pm 1.1 \times 10^{5} \mathrm{cpm} / \mu \mathrm{g}$ protein, and in crypt cells $\left[{ }^{3} \mathrm{H}\right]$ leucine incorporation was $7.7 \pm 6.7 \times 10^{3}(n=3)$. Fig. 4 shows that at all toxin concentrations studied, villus cells were 
Table II. Effects of Tetrodotoxin on Active Electrolyte Transport Changes Induced in Rabbit Jejunum by Exposure to Shiga Toxin

\begin{tabular}{|c|c|c|c|c|c|c|c|c|c|}
\hline Incubation conditions & $\mathbf{I}_{\mathbf{s c}}$ & PD & G & $\mathrm{J}_{\mathrm{ms}}^{\mathrm{Na}}$ & $\mathrm{J}_{\mathrm{sm}^{\mathrm{N}}}^{\mathrm{Na}}$ & $J_{\text {net }}^{\mathrm{Na}}$ & $\mathrm{J}_{\mathrm{ms}}^{\mathrm{Cl}}$ & $\mathrm{J}_{\mathrm{sm}}^{\mathrm{C}}$ & $\mathrm{J}_{\text {net }}^{\mathrm{Cl}}$ \\
\hline \multicolumn{10}{|c|}{ A. In vivo preincubation with buffer } \\
\hline 1 Buffer & $1.46 \pm 0.17$ & $-2.0 \pm 0.3$ & $21.2 \pm 2.0$ & $10.91 \pm 0.82$ & $9.66 \pm 0.71$ & $1.25 \pm 0.71$ & $7.91 \pm 0.47$ & $7.19 \pm 0.48$ & $0.72 \pm 0.70$ \\
\hline 2 Tetrodotoxin & $0.82 \pm 0.29$ & $-0.9 \pm 0.4$ & $26.4 \pm 2.0$ & $13.57 \pm 0.90$ & $11.55 \pm 0.72$ & $2.02 \pm 0.38$ & $9.65 \pm 0.84$ & $7.06 \pm 0.74$ & $2.59 \pm 1.26$ \\
\hline$\Delta 2-1^{\S}$ & $-0.65 \pm 0.15$ & $1.1 \pm 0.1$ & $5.2 \pm 1.2$ & $2.66 \pm 0.81$ & $1.89 \pm 0.37$ & $0.77 \pm 0.33$ & $1.74 \pm 0.55$ & $-0.13 \pm 0.95$ & $1.87 \pm 0.86$ \\
\hline$P$ value ${ }^{l l}$ & $<0.005$ & $<0.001$ & $<0.01$ & $<0.05$ & $<0.005$ & $<0.05$ & $<0.05$ & NS & $<0.05$ \\
\hline
\end{tabular}

B. In vivo preincubation with Shiga toxin

\begin{tabular}{|c|c|c|c|c|c|c|c|c|c|}
\hline 1 Buffer & $1.48 \pm 0.15$ & $-2.1 \pm 0.2$ & $19.4 \pm 0.8$ & $9.36 \pm 0.59$ & $9.87 \pm 1.81$ & $-0.50 \pm 0.79$ & $6.54 \pm 0.30$ & $7.57 \pm 0.32$ & $-1.03 \pm 0.49$ \\
\hline 2 Tetrodotoxin & $1.34 \pm 0.17$ & $-1.9 \pm 0.4$ & $19.4 \pm 1.1$ & $9.06 \pm 0.64$ & $10.97 \pm 0.52$ & $-1.91 \pm 0.77$ & $6.86 \pm 0.67$ & $7.35 \pm 0.56$ & $-0.49 \pm 0.50$ \\
\hline$\Delta 2-1^{\S}$ & $-0.13 \pm 0.16$ & $0.2 \pm 1.3$ & $0.0 \pm 1.3$ & $-0.31 \pm 0.78$ & $1.11 \pm 0.57$ & $-1.41 \pm 0.60$ & $0.32 \pm 0.71$ & $-0.22 \pm 0.45$ & $0.54 \pm 0.53$ \\
\hline$P$ value & NS & NS & NS & NS & NS & NS & NS & NS & NS \\
\hline$P$ value" & $<0.05$ & NS & $<0.025$ & $<0.05$ & NS & $<0.02$ & NS & NS & NS \\
\hline
\end{tabular}

Units and conditions as in Table I, with two 20 -min flux periods (1. Buffer) followed by serosal addition of $10^{-8} \mathrm{M}$ tetrodotoxin and then two further 20-min flux periods (2. Tetrodotoxin). ${ }^{*}$ Mucosa-to-serosa unidirectional flux. ${ }^{\ddagger}$ Serosa-to-mucosa unidirectional flux. ${ }^{\S}$ Difference between tetrodotoxin-treated period (2) and control period (1). " $P$ value of difference between tetrodotoxin treated and control period.

" $P$ value of difference between tetrodotoxin treated and control period $(\Delta 2-1)$ from control or Shiga toxin preincubated tissue (A vs. B).

more susceptible to the protein synthesis inhibitory effect of Shiga toxin than were crypt cells.

The next experiment was designed to determine whether the failure of toxin to alter crypt cell function was due to a lack of sensitivity of these cells to the action of toxin, or if this was an artefact related to the much lower in vitro incorporation rate of leucine by crypt cells (26). Therefore, the effect of cycloheximide $(1 \mathrm{mg} / \mathrm{ml})$ on protein synthesis was assessed under the same conditions used for the Shiga toxin experiments. $\left[{ }^{3} \mathrm{H}\right]$ Leucine incorporation in cycloheximide-exposed villus and crypt cells was inhibited to a similar degree $(7.4 \pm 4.9 \%$ and $11.1 \pm 5.1 \%$ of the level in control cells, respectively). Thus, the explanation for the lack of effect of Shiga toxin on protein synthesis in crypt cells is unlikely to be related

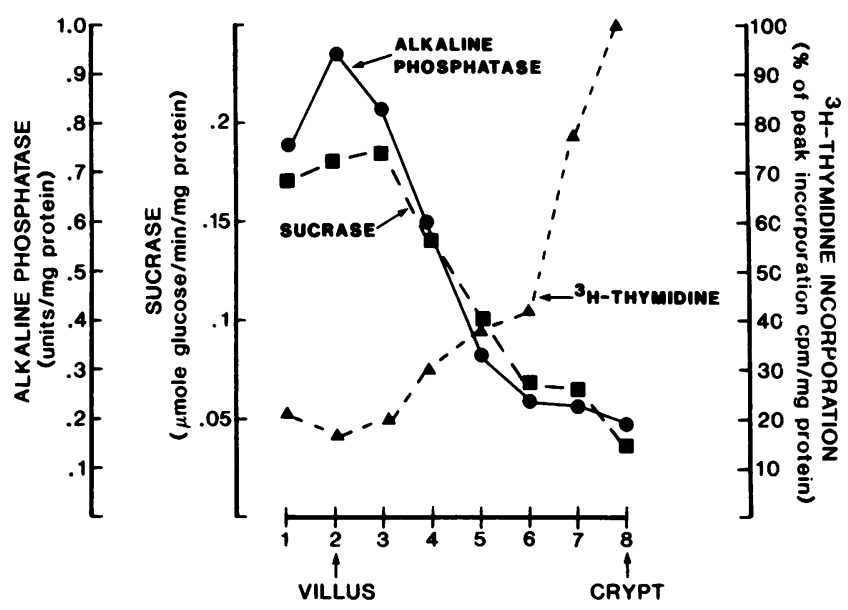

Figure 3. Villus and crypt cells were obtained by the Weiser method (12) as described in Methods. To characterize the cell populations, sucrase activity (squares), alkaline phosphatase activity (circles), and $\left[{ }^{3} \mathrm{H}\right]$ thymidine incorporation into DNA (triangles) were assayed in each isolated epithelial cell fraction. Results shown are the mean of triplicate determinations from each of three cell separations using tissue from different animals. Cell fraction number is indicated on the abscissa. simply to the low levels of protein turnover in vitro we observed.

Shiga toxin binding to jejunal epithelial cells. We next explored the possibility that the difference in responsiveness to toxin between villus and crypt cells was related to differences in the ability of these cells to bind toxin. Both isolated villus and crypt cells bound ${ }^{125} \mathrm{I}$-toxin in a concentration dependent and saturable manner (Fig. 5, $A$ and $B$ ). Scatchard analyses revealed a 60 -fold greater number of binding sites on villus cells $(18.75 \mathrm{pmol} / \mathrm{mg}$ protein $)$ than on crypt cells $(0.31 \mathrm{pmol} /$ mg protein), and the straight line plot obtained was consistent with a single class of receptors, as our laboratory previously reported for isolated rabbit microvillus membranes $(16,17)$. To convert these data to a per cell basis, cells were counted in a hemocytometer chamber and the relationship between number of cells and amount of cell protein was calculated. These values were used as a correction factor $\left(6.6 \pm 3.2 \times 10^{6}\right.$ cells $/ \mathrm{mg}$ villus cell protein, and $1.2 \pm 2.1 \times 10^{7}$ cells/mg crypt cell protein; $n=3$ determinations), and the binding data were recalculated. By this method, there were $1.7 \times 10^{6}$ Shiga toxin

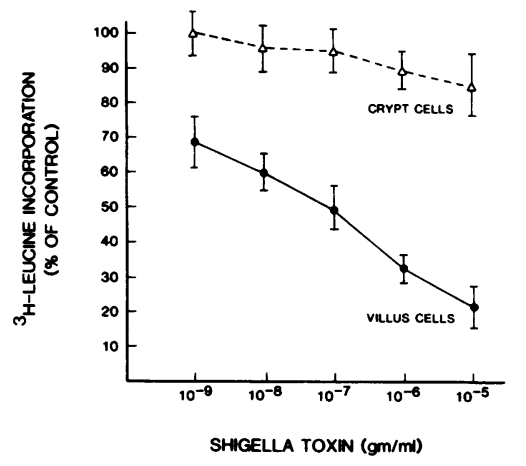

Figure 4. Effect of Shiga toxin on in vitro $\left[{ }^{3} \mathrm{H}\right]-$ leucine incorporation into protein in rabbit jejunal epithelial cells. Equal amounts of cell protein from villus cells (epithelial cell fraction 2 ; closed circles) and crypt cells (epithelial cell fraction 8; open triangles) were incubated in vitro with media containing buffer only

or serial dilutions of Shiga toxin. 30 min later, cells were pulsed with $\left[{ }^{3} \mathrm{H}\right.$ ]leucine for $15 \mathrm{~min}$ and incorporated radioactivity in the $10 \%$ TCA insoluble fraction was measured. Results are shown as mean $\pm \mathrm{SE}$ of three determinations, and are expressed as the percentage of the radioactivity in control (buffer only) cells. 

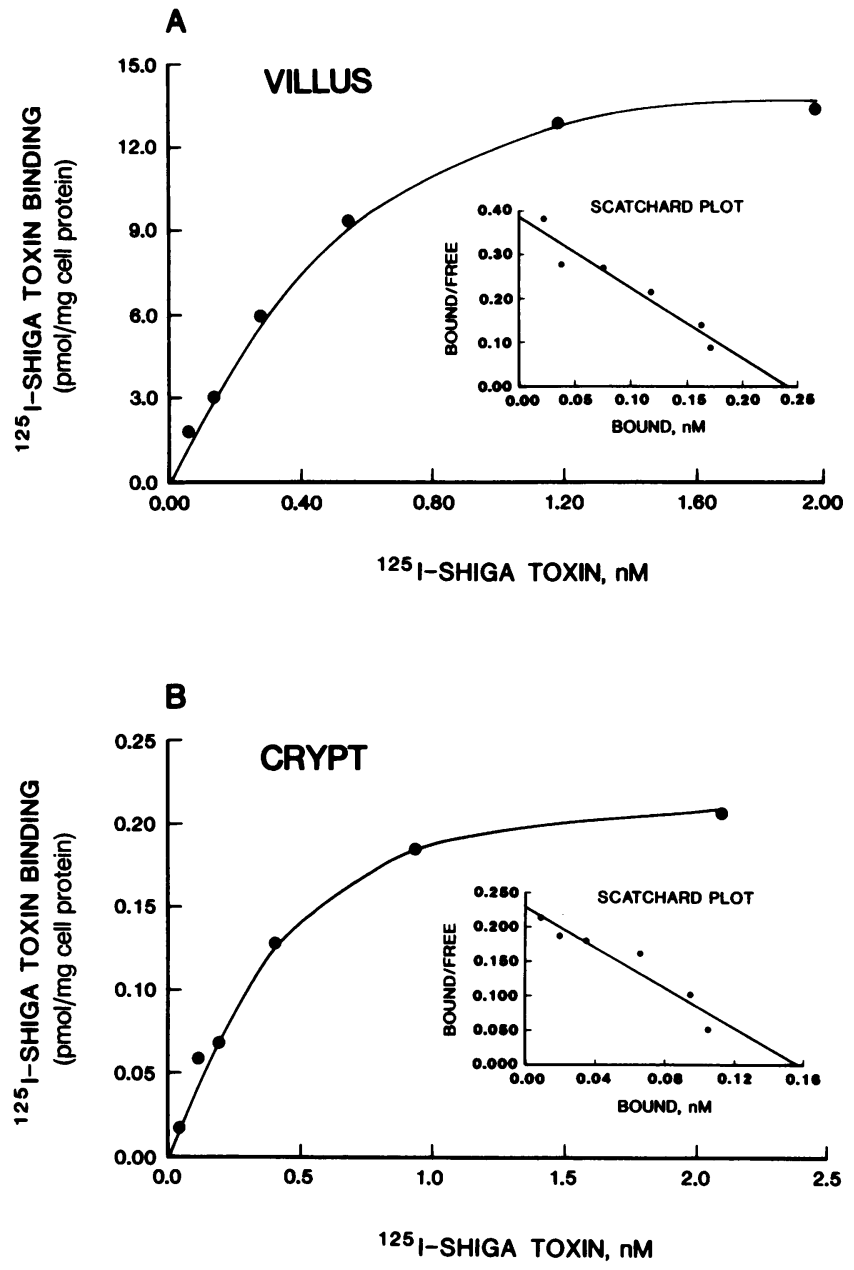

Figure 5. Specific ${ }^{125} \mathrm{I}$-Shiga toxin binding to villus (epithelial cell fraction 2) (6A) and crypt cells (epithelial cell fraction 8) (6B). Increasing concentrations of ${ }^{125}$ I-labeled Shiga toxin were incubated with $2.5 \mu \mathrm{g}$ of villus cell protein or $100 \mu \mathrm{g}$ of crypt cell protein for 45 min at $4^{\circ} \mathrm{C}$. Specific binding was measured as described in Methods in three separate experiments with similar results. The results of a representative experiment are shown here. The Scatchard plots of the same binding data are displayed in the inserts.

receptors per villus cell, and only $1.5 \times 10^{4}$ per crypt cell. The calculated $K_{\mathrm{d}}$ for villus cells $\left(6.2 \times 10^{-10} \mathrm{M}\right)$ was comparable to that for crypt cells $\left(6.9 \times 10^{-10} \mathrm{M}\right)$.

To further study toxin binding ability along the villus-crypt axis, each cell population was solubilized, subjected to SDSPAGE, and exposed to ${ }^{125}$ I-labeled toxin in order to detect components able to bind toxin. Coomassie brilliant blue staining revealed an identical protein band pattern in all 8 cell fractions (Fig. 6, top). The accompanying autoradiogram (Fig. 6 , bottom) showed that iodinated toxin bound to the dye front of the gel, which is consistent with the location of the previously described glyco-lipid Gb3 receptor in SDS-PAGE gels (17). Binding also decreased gradually along the gradient from villus to crypt, with the crypt cell fraction 8 being virtually devoid of toxin binding ability. Binding was specific, as it was abolished when the gels were incubated first in the presence of an excess of unlabeled toxin. When ${ }^{125}$ I-cholera toxin was substituted for Shiga toxin in the same protocol, equivalent binding to the dye front (where $\mathrm{GM}_{1}$ ganglioside migrates) was

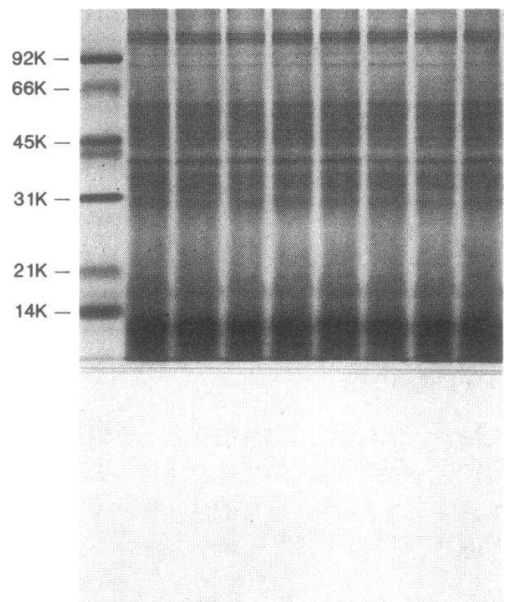

Figure 6. Binding of ${ }^{125}$ I-Shiga toxin to rabbit jejunal epithelial cells separated by the method of Weiser (12) and analyzed by SDSpolyacrylamide gel electrophoresis. Equal amounts of cell protein $(50 \mu \mathrm{g})$ from each of the eight epithelial cell fractions obtained were electrophoresed as described in Methods. Multiple bands were present by Coomassie brilliant blue staining (top). The gel was then overlaid with ${ }^{125} \mathrm{I}$-labeled Shiga toxin $(100,000 \mathrm{cpm} / \mathrm{ml})$ and prepared for autoradiography (bottom). Shiga toxin bound to components of rabbit jejunal epithelial cells present at the dye front, and decreased along the villus cell to crypt cell gradient from lanes 1 to 8 . Lane $S$ contains a series of molecular weight markers. Similar data were obtained in three experiments, and a representative gel and autoradiogram is shown.

present in all cell fractions, including fraction 8 (data not shown). In addition, ${ }^{125}$ I-cholera toxin bound to several protein bands, as previously observed by others $(27,28)$.

Immunoperoxidase staining. One explanation for the difference in toxin binding capacity between villus cells and crypt cells is that the toxin receptor is lost during the prolonged EDTA DTT incubation of the rabbit jejunum required for crypt cell isolation by the Weiser method. To examine this possibility, and to determine if differences in villus-crypt binding are detectable in intact intestinal tissue, a direct immunoperoxidase technique using biotinylated anti-toxin antibody was employed, as described in Methods. Brown reaction product indicating toxin binding was present along the villus surface but was not observed in the crypts of cryotome sections from normal rabbit jejunum (data not shown). Control sections incubated with cholera toxin $(1 \mu \mathrm{g} / \mathrm{ml})$ and anti-Shiga toxin antibody revealed a light brown background staining of the muscularis, but no reaction with the epithelial cells.

Glycolipid analysis. High performance thin-layer chromatography of chloroform/methanol extracts of villus and crypt cells was performed to characterize the toxin binding component in the cells. A neutral glycolipid migrating in the region of authentic nonhydroxylated erythrocyte $\mathrm{Gb} 3$ and consistent with the location of hydroxylated gut $\mathrm{Gb} 3$ (29) was present in villus cells and not in crypt cells (Fig. 7, left), whereas other lipids visualized were common to both cell types. Iodinated Shiga toxin bound to just the $\mathrm{Gb} 3$ band and only in villus cells (Fig. 7, right).

\section{Discussion}

All known bacterial enterotoxins, as well as most other protein secretagogues, cause fluid accumulation in the intestinal lumen by inhibiting $\mathrm{NaCl}$ absorption while simultaneously stimulating anion secretion. Our results indicate that Shiga 


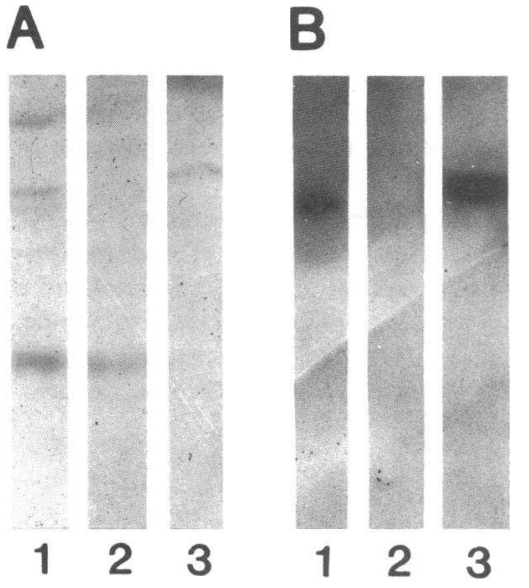

Figure 7. Binding of ${ }^{125}$ I-Shiga toxin to lipids extracted from rabbit jejunal epithelial cells and separated by highperformance thin-layer chromatography (HPTLC). Total lipids were extracted from 1 $\mathrm{mg}$ protein of either villus cells (lane 1 ) or crypt cells (lane 2) with isopropanol/hexane/ water $(55: 25: 20)$, dried, and solubilized in 100 $\mu l$ of chloroform/methanol (2:1). $5 \mu \mathrm{l}$ of this material was spotted on

HPTLC plates using a chloroform/methanol/water (50:40:10) solvent system. Purified erythrocyte globotriaosylceramide (Gb3), the known glycolipid Shiga toxin receptor, was included in lane 3 as a standard. Orcinol staining of separated glycolipids $(A$, left $)$ showed both common and unique bands in the two epithelial cell preparations. Autoradiography of a duplicate plate incubated with ${ }^{125} \mathrm{I}$-Shiga toxin $(B, r i g h t)$ demonstrated a single band in the villus cell extract migrating in the region of the Gb3 standard that bound toxin.

toxin is unusual in this respect in that, at least in rabbit jejunum, it appears to inhibit $\mathrm{Na}$ and $\mathrm{Cl}$ absorption without affecting active anion secretion. The evidence for this assertion comes from the experiments in which rabbit jejunum, preincubated in vivo with Shiga toxin, was studied with the Ussing chamber voltage-clamp technique. We were careful to perform these experiments at a time during which single-pass perfusion studies indicated that toxin was causing net fluid accumulation in the jejunal lumen. We found that the basal short-circuit current (an index of anion secretion) of toxin-incubated jejunal mucosa was not significantly different from control tissue, and that the incremental increases in short-circuit current after stimulation with a concentration of theophylline that leads to maximum $\mathrm{Cl}$ secretion was also comparable to control. These observations indicate that Shiga toxin does not stimulate active anion secretion, a crypt cell function. In contrast, glucose- and alanine-stimulated $\mathrm{Na}$ absorption were both significantly diminished in the Shiga toxin-incubated tissue. In addition, unidirectional ${ }^{22} \mathrm{Na}$ and ${ }^{36} \mathrm{Cl}$ fluxes demonstrated that Shiga toxin exposure inhibited non-substrate dependent $\mathrm{Na}$ and $\mathrm{Cl}$ absorption, with approximately equal decreases in mucosa-to-serosa and net fluxes of $\mathrm{Na}$ and $\mathrm{Cl}$. Thus, multiple aspects of $\mathrm{Na}$ absorption were inhibited by Shiga toxin. It has not been conclusively established whether rabbit jejunum possesses "neutral" $\mathrm{NaCl}$ absorption, a process in which one molecule of $\mathrm{Na}$ is absorbed with one molecule of $\mathrm{Cl}$. However, the similar inhibition by Shiga toxin of an electroneutral process in which equal inhibition of mucosa-to-serosa and net $\mathrm{Na}$ and $\mathrm{Cl}$ fluxes occurs, is compatible with an action on such a process.

Our experiments also provide an explanation for the selective action of Shiga toxin on electrolyte absorption. Villus cells, the specific cell believed to carry out electrolyte absorption (25), were more susceptible to toxin-induced inhibition of protein synthesis than were crypt cells, which are anion secretory cells. This selectivity is consistent with the presence of a large excess of the neutral glycolipid Shiga toxin receptor, Gb3, on villus cells compared to crypt cells. The slight difference in the migration on HPTLC plates of villus cell $\mathrm{Gb} 3$ compared to erythrocyte $\mathrm{Gb} 3$ standard is due to variability in hydroxylation of the lipid moiety (29). Preferential binding of the toxin to villus cells was also documented by immunoperoxidase visualization of toxin binding to intact rabbit jejunal mucosal sections.

However, while our studies demonstrate Shiga toxin specific binding to villus cells, we have not established that the transport effects are exerted entirely at the villus $\mathrm{Na}$ absorbing cells. Experiments were therefore also performed to determine whether tetrodotoxin sensitive nerves were involved in the toxin effect, by comparing the magnitude of tetrodotoxin stimulation of $\mathrm{Na}$ and $\mathrm{Cl}$ absorption in jejunum exposed to Shiga toxin or to buffer. A larger increase in toxin-treated tissue would have indicated that Shiga toxin acted at least partially through tetrodotoxin-sensitive nerves. We found instead a smaller tetrodotoxin stimulation of $\mathrm{Na}$ and $\mathrm{Cl}$ absorption in toxin treated tissue, which is compatible with the general decrease in $\mathrm{Na}$ absorption caused by toxin exposure and is against a role for nerves in the Shiga toxin effect. However, because of the general suppression of $\mathrm{Na}$ absorption by Shiga toxin the results cannot be considered conclusive. We cannot yet be certain whether part of the toxin effects on transport might be mediated via toxin initiation of arachadonic acid metabolism by either the cyclooxygenase or lipoxygenase pathways, products of both of which affect active intestinal ion transport.

A relatively small number of toxin binding sites were detected on crypt cells (Fig. 5), consistent with the minimal effect on leucine incorporation we observed in the crypt cell population following exposure to toxin (Fig. 4). This degree of inhibition of protein synthesis can also be accounted for by as little as a $1 \%$ contamination of the crypt cell fraction with villus cells, which is possible in gut cell separations by the Weiser method. Thus, we conclude that Shiga toxin is highly specific for villus cells. Keenan et al. have previously drawn the same conclusion from high resolution light and scanning and transmission electron microscopy studies (30). Their data demonstrate that purified Shiga toxin selectively damages villus epithelial cells in rabbit ileum, leaving crypt cells and goblet cells intact.

The experiments described in the present report are the first clear demonstration of an effect of purified Shiga toxin on intestinal electrolyte transport. The importance of using purified toxin is underscored by several differences between the reported effects of crude toxin and purified toxin. Crude toxin preparations are known to cause an inflammatory infiltrate in the lamina propria of the ileum $(31,32)$ and alterations in the myoelectrical activity of the muscularis (33). These phenomena have not been demonstrated with purified toxin $(30,34)$. Donowitz et al. reported that crude Shiga toxin increases mucosal conductance and increases serosa-to-mucosa $\mathrm{Na}$ fluxes in rabbit ileum (32), whereas in the present studies with purified toxin and rabbit jejunum neither effect was observed. They also reported that crude Shiga toxin blunts glucose-stimulated $\mathrm{Na}$ transport but does not alter basal short-circuit current or the incremental increase in short-circuit current after serosal theophylline, similar to the findings in this paper.

What then is the mechanism by which Shiga toxin causes accumulation of fluid in the gut lumen? Most studies using crude Shiga toxin have concluded that activation of adenylate 
cyclase is not necessary to cause toxin-induced fluid secretion $(32,35)$, although in one report adenylate cyclase activity was enhanced (36). The normal secretory response caused by theophylline in tissue exposed to purified Shiga toxin reported here further indicates the lack of involvement of adenylate cyclase in mediating the effects of Shiga toxin on transport. It is therefore tempting to speculate that the enzymatic action of Shiga toxin, which results in profound inhibition of protein synthesis, also underlies its ability to induce fluid accumulation in the intestinal lumen of experimental animals. Accordingly, a model explaining the in vivo "secretory" action of Shiga toxin can be proposed. Evidence presented here, and elsewhere $(16,17,22)$, indicates that the first step in the gut cell-toxin interaction is the binding of toxin to $\mathrm{Gb3}$ on the villus cell brush border membrane. The toxin is subsequently internalized, probably by receptor-mediated endocytosis, as shown for HeLa or Vero cells $(37,38)$, in order to reach its ribosomal site of action. The resulting inhibition of protein synthesis presumably leads to impaired villus cell absorptive function. Crypt cells are not affected by toxin because they appear to lack sufficient quantities of the glycolipid toxin receptor, Gb3. Consequently the basal crypt cell anion secretion is "unmasked," leading to accumulation of fluid in the intestinal lumen. This lack of a dual effect on both villus and crypt cell functions may explain why maximal secretory doses of Shiga toxin always result in less net secretion than comparable studies with cholera toxin $(1,8,17)$, and why addition of cholera toxin to rabbit ileal loops preincubated with Shiga toxin leads to further fluid accumulation (8). Furthermore, the previous report that Shiga toxin inhibits intestinal galactose and alanine uptake (39) is in keeping with a global derangment of villus cell absorptive function caused by the toxin. As the final event, irreversible inhibition of villus cell protein synthesis eventually would lead to morphological changes in the villus cell and cell death. Histological alterations have indeed been reported in most studies examining the effects of Shiga toxin in vivo $(8,30,31)$.

While the bulk of the available evidence supports this proposed mechanism, the link between inhibition of villus cell protein synthesis and inhibition of villus cell electrolyte absorption remains to be established. However, we cannot definitively separate changes in jejunal sodium absorption due to a specific effect of Shiga toxin on jejunal absorptive cells from an effect due to "cytotoxicity" resulting from inhibition of protein synthesis. Although Shiga toxin diminished $\left[{ }^{3} \mathrm{H}\right]$ leucine incorporation into mucosal (mainly villus cell) protein in these studies, another presently unknown property of the toxin could still be responsible for its observed antiabsorptive effects. We raise this possibility because cycloheximide, which inhibits protein synthesis in both villus and crypt cells, diminishes, rather than enhances, the intestinal fluid secretion induced by cholera toxin (6) and by luminal hypertonic solutions (7). Moreover, cycloheximide alone does not significantly alter luminal fluid movement or net $\mathrm{NaCl}$ fluxes (6), in contrast to the effects we observed with Shiga toxin. But it is important to note that cyclohexamide is a small molecular weight protein that is transported across all cell membranes; thus it affects both villus and crypt cells equally. It is possible that this explains why the influence of parenterally administered cycloheximide on intestinal electrolyte transport is different from that of Shiga toxin, which exclusively targets villus cells and is delivered via the gut lumen.

\section{Acknowledgments}

We gratefully acknowledge the expert help of Dr. Mary Jacewicz for the lipid analyses, Dr. Ron DeLellis for immunoperoxidase staining, and Ms. Meetha Gould and Mr. Chris Perry for their assistance in Ussing chamber studies.

Supported in part by National Institutes of Health grants AI-16242, AI-20235, DK-26523, and Center Grant DK-34928 (Center for Gastrointestinal Research on Absorptive and Secretory Processes) and a Rockefeller Foundation Grant in Geographic Medicine. Dr. Kandel was a post-doctoral research fellow of the Medical Research Council of Canada, and is presently at The Wellesley Hospital, Toronto, Ontario, Canada.

\section{References}

1. Keusch, G. T., A. Donohue-Rolfe, and M. Jacewicz. 1985. Shigella toxin and the pathogenesis of shigellosis. In Microbial Toxins and Diarrhoeal Disease. D. Evered and J. Whelan, editors. Ciba Foundation Symposium 112. Pitman Publishers, London. 193-214.

2. Keusch, G. T., G. F. Grady, L. J. Mata, and J. McIver. 1972. The pathogenesis of Shigella diarrhea. I. Enterotoxin production by Shigella dysenteriae 1. J. Clin. Invest. 51:1212-1218.

3. O'Brien, A. D., and R. K. Holmes. 1987. Shiga and Shiga-like toxin. Microbiol. Rev. 51:206-220.

4. Reisbig, R., S. Olsnes, and K. Eiklid. 1981. The cytotoxic activity of Shigella toxin. Evidence for catalytic inactivation of the $60 \mathrm{~S}$ ribosomal subunit. J. Biol. Chem. 256:8739-8744.

5. Endo, Y., K. Tsurugi, T. Yutsudo, Y. Takeda, T. Okasawara, and K. Igaraski. 1988. Site of action of a Vero toxin (VT2) from Escherichia coli 0157:H7 and of Shiga toxin on eukaryotic ribosomes. RNA N-glycosidase activity of the toxins. Eur. J. Biochem. 171:45-50.

6. Kimberg, D. V., M. Field, E. Gershon, R. Schooley, and A. Henderson. 1973. Effects of cycloheximide on the response of intestinal mucosa to cholera enterotoxin. J. Clin. Invest. 52:1376-1383.

7. Halsted, C. H., D. I. Grayer, E. H. Leubbers, J. H. Yardley, and T. R. Hendrix. 197.1. Effect of cycloheximide on intestinal secretion induced by hypertonic glucose. Gut. 12:262-267.

8. Steinberg, S. E., J. G. Banwell, J. H. Yardley, G. T. Keusch, and T. R. Hendrix. 1975. Comparison of secretory and histological effects of shigella and cholera enterotoxins in rabbit intestine. Gastroenterology. 68:309-317.

9. Donohue-Rolfe, A., G. T. Keusch, C. Edson, D. Thorley-Lawson, and M. Jacewicz. 1984. Pathogenesis of Shigella diarrhea. IX. Simplified high-yield purification of shigella toxin and characterization of subunit composition and function by the use of sub-unit specific monoclonal and polyclonal antibodies. J. Exp. Med. 160:17671781.

10. Charney, A. N., and M. Donowitz. 1976. Prevention and reversal of Cholera enterotoxin-induced intestinal secretion by methylprednisolone induction of $\mathrm{Na}^{+}-\mathrm{K}^{+}$-ATPase. J. Clin. Invest. 57:15901599.

11. Donowitz, M., and N. Asarkof. 1982. Calcium dependence of basal electrolyte transport in rabbit ileum. Am. J. Physiol. 243:G28G35.

12. Weiser, M. M. 1973. Intestinal epithelial cell surface membrane glycoprotein synthesis. I. An indicator of cellular differentiation. $J$. Biol. Chem. 248:2536-2541.

13. Dahlqvist, A. 1968. Assay of intestinal disaccharidases. Anal. Biochem. 22:99-107.

14. Lentze, M., P. C. Colony, and J. S. Trier. 1985. Glucocorticoid receptors in isolated intestinal epithelial cells in rats. Am. J. Physiol. 249:G58-G65.

15. Koo, F. C. W., J. W. Peterson, C. W. Houston, and N. C. Molina. 1984. Pathogenesis of experimental salmonellosis: inhibition of protein synthesis by a cytotoxin. Infect. Immun. 43:93-100.

16. Fuchs, G., M. Mobassaleh, A. Donohue-Rolfe, R. K. Montgomery, R. J. Grand, and G. T. Keusch. 1986. Pathogenesis of Shigella 
diarrhea: rabbit intestinal cell microvillus membrane binding site for shigella toxin. Infect. Immun. 53:372-377.

17. Mobassaleh, M., A. Donohue-Rolfe, M. Jacewicz, R. J. Grand, and G. T. Keusch. 1988. Pathogenesis of shigella diarrhea: Evidence for a developmentally regulated glycolipid receptor for shigella toxin involved in the fluid secretory response of rabbit small intestine. $J$. Infect. Dis. 157:1023-1031.

18. Dharmalingam, K., and E. C. Goldberg. 1979. Restriction in vivo III. General effects of glucosylation and restriction on phage T4 gene expression and replication. Virology. 96:393-403.

19. Burridge, K. 1976. Changes in cellular glycoproteins after transformation: identification of specific glycoproteins and antigens in sodium dodecyl sulfate gels. Proc. Natl. Acad. Sci. USA. 12:44574461.

20. Hudson, L., and F. C. Hay. 1980. Practical Immunology. Blackwell Scientific, Oxford. 1-3.

21. Bayer, E. A., and M. Wilchek. 1980. The use of the avidin-biotin complex as a tool in molecular biology. Methods Biochem. Anal. 26:1-42.

22. Jacewicz, M., H. Clausen, E. Nudelman, A. Donohue-Rolfe, and G. T. Keusch. 1986. Pathogenesis of Shigella diarrhea. XI. Isolation of a shigella toxin-binding glycolipid from rabbit jejunum and HeLa cells and its identification as globotriasylceramide. J. Exp. Med. 163:1391-1404.

23. Lindberg, A. A., J. E. Brown, N. Stromberg, M. Westling-Ryd, J. E. Schultz, and K. A. Karlsson. 1987. Identification of the carbohydrate receptor for Shiga toxin produced by Shigella dysenteriae type 1 . J. Biol. Chem. 262:1779-1785.

24. Nudelman, E., R. Kannagi, S. Hakomori, M. Parsons, M. Lipinski, J. Wiels, M. Fellous, and T. Tursz. 1983. A glycolipid antigen associated with Burkitt Lymphoma defined by a monoclonal antibody. Science (Wash. DC). 220:509-511.

25. Donowitz, M., and M. J. Welsh. 1987. Regulation of mammalian small intestinal electrolyte secretion. In Physiology of the Gastrointestinal Tract. L. R. Johnson, editor. 2nd edition. Raven Press, New York. 1351-1388.

26. Alpers, D. H. 1977. Protein turnover in intestinal mucosal villus and crypt brush border membranes. Biochem. Biophys. Res. Commun. 75:130-135.

27. Morita, A., D. S. Rsao, and Y. S. Kim. 1980. Identification of cholera toxin binding glycoproteins in rat intestinal microvillus membranes. J. Biol. Chem. 255:2549-2553.
28. Critchley, D. R., J. L. Magnani, and P. H. Fishman. 1981. Interaction of cholera toxin with rat intestinal brush border membranes. J. Biol. Chem. 276:8721-8731.

29. Mobassaleh, M., S. K. Gross, R. H. McCluer, A. DonohueRolfe, and G. T. Keusch. 1989. Quantitation of the rabbit intestinal glycolipid receptor for Shiga toxin. Further evidence for the developmental regulation of globotriaosylceramide in microvillus membranes. Gastroenterology. 97:384-391.

30. Keenan, K. P., D. D. Sharpnack, S. B. Formal, and A. D. O'Brien. 1986. Morphological evaluation of the effects of Shiga toxin and $E$. coli Shiga-like toxin on the rabbit intestine. Am. J. Pathol. 125:69-80.

31. Keusch, G. T., G. F. Grady, A. Takeuchi, and H. Sprinz. 1972. The pathogenesis of Shigella diarrhea. II. Enterotoxin-induced acute enteritis in the rabbit ileum. J. Infect. Dis. 126:92-95.

32. Donowitz, M., G. T. Keusch, and H. J. Binder. 1975. Effect of Shigella enterotoxin on electrolyte transport in rabbit ileum. Gastroenterology. 1230-1237.

33. Mathias, J. R., G. M. Carlson, J. L. Martin, R. P. Shields, and S. B. Formal. 1980. Shigella dysenteriae I enterotoxin: proposed role in pathogenesis of shigellosis. Am. J. Physiol. 239:G382-G386.

34. Fernandez, A., C. A. Sninsky, A. D. O'Brien, M. H. Clench, and J. R. Mathias. 1984. Purified Shigella enterotoxin does not alter intestinal motility. Infect. Immun. 43:477-481.

35. Flores, J., G. Grady, J. McIver, P. Witkum, B. Beckman, and G. W. G. Sharp. 1974. Comparison of the effects of enterotoxins of Shigella dysenteriae and Vibrio cholerae on the adenylate cyclase system of the rabbit intestine. J. Infect. Dis. 130:374-379.

36. Charney, A. N., R. E. Gots, S. B. Formal, and R. A. Giannella. 1976. Activation of intestinal mucosal adenylate cyclase by Shigella dysenteriae I enterotoxin. Gastroenterology. 70:1085-1090.

37. Jacewicz, M., and G. T. Keusch. 1983. Pathogenesis of Shigella diarrhea. VIII. Evidence for a translocation step in the cytotoxic action of Shiga toxin. J. Infect. Dis. 148:844-854.

38. Sandvig, K., S. Olsnes, J. E. Brown, O. W. Petersen, B. and B. van Deurs. 1989. Endocytosis from coated pits of Shiga toxin: a glycolipid-binding protein from Shigella dysenteriae 1. J. Cell Biol. 108:1331-1343.

39. Binder, H. J., and D. S. Whiting. 1977. Inhibition of small-intestinal sugar and amino acid transport by the enterotoxin of Shigella dysenteriae I. Infect. Immun. 16:510-512. 